\title{
History, Cultural Memory and Intermediality in Radu Jude's Aferim!
}

\author{
Judit Pieldner \\ Sapientia Hungarian University of Transylvania (Romania) \\ E-mail: juditpieldner@gmail.com
}

\begin{abstract}
A historical drama that can be interpreted at the juncture of theoretical discourses (heritage film, auteur film), genres (historical film, western, road movie) and representational modes (connecting to, but subverting the master narrative of Romanian historical cinema), Radu Jude's Aferim! (2015) has attracted the attention of the international public by the unique response that it gives to the tradition of representation of the (Romanian) historical past. Its unmatched character even within New Romanian Cinema can be attributed to the fact that it does not focus on tensions of the post-communist condition or their antecedents in the recent communist past; instead, it goes back in history to a much earlier period, to the Romanian ancien régime, after the Ottoman occupation and before the abolition of Gypsy slavery, only to point at the historical roots of current social problems. Through its ingenuous (inter)medial solutions (black-and-white film, with an implied media-archaeological purport; period mise en scène but with an assumed artificiality and constructedness; a simple linear plot infused with a dense dialogue in archaic Romanian, drawn from a multitude of literary and historical sources; a sweeping panorama of $19^{\text {th }}$-century Wallachian society presented in a succession of tableau compositions), Radu Jude's ironical-critical collage defetishizes the traditional historical iconography and debunks the mythical national imaginary, unveiling the traumatic history of an ethnic and racial mix. ${ }^{1}$
\end{abstract}

Keywords: cultural memory, western, allegory, intermediality, tableau, collage.

Radu Jude's Aferim! (2015), screened at the $65^{\text {th }}$ Berlin International Film Festival, where Radu Jude was awarded the Silver Bear for Best Director, and with the biggest domestic viewer number in 2015, has also attracted the attention of the international public by the unique response that it gives to the tradition - and

1 This work was supported by a grant of the Romanian Ministry of National Education, CNCS UEFISCDI, project number PN-II-ID-PCE-2012-4-0573. 
challenge - of representation of the (Romanian) historical past. Its unmatched character even within New Romanian Cinema can be assigned to the fact that it does not focus on tensions of the post-communist condition or their antecedents in the recent communist past as most attempts at micro-realist representation do; instead, it turns back in history to a much earlier period, to the first half of the $19^{\text {th }}$ century. This cinematic gesturing towards the distant Romanian historical past has multiple connections with, and at the same time is disrupted from, various representational traditions.

What Aferim! is can probably be best understood in terms of what it is not: first and foremost, from the character and purpose of the heritage film. Belén Vidal starts her volume Heritage Film: Nation, Genre and Representation by outlining the main traits of the heritage film: "[u]nlike the western, the romantic comedy or the horror film, the heritage film is not a genre in the industrial sense of the term. Rather, the concept has its roots in British film studies, where it has become associated with a powerful undercurrent of nostalgia for the past, conveyed by historical dramas, romantic costume films and literary adaptations. These films often flaunt their connections with classical works of the literary canon, lavish production values and star performances" $(2012,1)$. Whether called period film, costume film or costume drama, heritage film is "a type of film that places its characters in a recognizable moment of the past, enhanced by the mise-en-scène of historical reconstruction" (Vidal 2012, 1). Heritage film constructs an imaginary reality with the claim of authentic representation, "trading on a nostalgic view of history as an attractive commodity and promising escape into worlds safely located in the past" (Vidal 2012, 16). As Aga Skrodzka remarks in discussing heritage film as compared to the vernacular cinema after the 1990s, "heritage genre envisions premodernity as times of truer, purer and more stable collective identity" (Skrodzka 2012, 32).

Aferim! returns to premodern times but not with the above-mentioned disposition of the heritage film. In terms of period mise en scène and authenticity of period detail, Aferim! evokes the heritage film, but only to get distanced from it by creating a counter-nostalgic image of the past and also by inducing a sense of artificiality. Thus, instead of creating an opulent image of the past that reinforces the national and collective identity of the present, Aferim! unveils a terrain of cultural anxiety with the aim of pointing at the historical roots of current mentalities and demystifying the national image of the past. Radu Jude's highly original film experiment is definitely an auteurist achievement and, as Belén Vidal states, "auteurist and heritage discourses remarkably exclude each other" $(2012,27)$. 
Aferim!, greeted as "something new in Romanian cinema” (Lazăr and Gorzo 2014), touches on the issue of Gypsy slavery in the period of the Romanian ancien régime, after the Ottoman occupation and before the liberation of Gypsy slaves. Set in early $19^{\text {th }}$-century Wallachia, the plot may be regarded as flexibly matching the narrative construct typical of westerns and road movies: a constable, Costandin (played by Teodor Corban), is hired by a boyar, Iordache (Alexandru Dabija), to find a Gypsy slave, Carfin (Toma Cuzin), who has run away from his estate after having an affair with his wife. On their way, Costandin and his son, Ioniță (Mihai Comănoiu), meet all kinds of members of $19^{\text {th }}$-century society, providing a possible viewpoint from which society can be represented. This is, however, not the outsider's critical viewpoint typical of the picaresque tradition: Costandin's remarks, formulated as lessons for his son, literary quotes in fact from a great number of $19^{\text {th }}$-century authors, echo the working mechanism of the society of the time, confirming and accepting the abuses as being the normal course of life, the way of the world, the persisting and unalterable order. In the end the Gypsy slave is brutally punished by the boyar, who cuts his testicles with a pair of scissors.

A historical drama that can be interpreted at the juncture of theoretical discourses (heritage film, auteur film), genres (historical film, western, road movie) and representational modes (connecting to, but subverting the master narrative of Romanian historical film), Aferim! is a revelatory response to the tradition of national cinema. Film is a "medium of cultural memory," characterized by its power, together with literature and other forms of medial externalization, "to shape the collective imagination of the past" (Erll 2008, 396, 389). In connection with the recent Thirld World cinema, reflecting the social changes that have taken place from the second half of the $20^{\text {th }}$ century on, Ismail Xavier highlights the significance of "the cinema as an instance of the affirmation of emerging national values, a key factor in the construction of national identity" $(2004,355)$. A quarter of a century after the regime change in Romania, however, in his latest film production, Radu Jude critically reflects on the historical role of cinema in the construction of Romanian national identity.

Through its concern with history, Aferim! initiates an architextual dialogue with the Romanian historical film tradition initiated by the 1912 silent film The Independence of Romania [Independența României], subtitled The RomanianRusso-Turkish War 1877, directed by Aristide Demetriade, and continued by a long series of historical films including Sergiu Nicolaescu's films created during the communist period. During the decades of communism, historical film 
genre formed part of ideological appropriation, moulding history in the way it best served propaganda purposes, showing an image of history that provided heroic models as edifying patterns of identification and meant to contribute to reinforcing Romanian national identity. Sergiu Nicolaescu was one of the most popular film directors who created historical dramas evoking the birth of the Romanian nation, glorious events, epic battles and collective sacrifices. ${ }^{2}$ Almost all historical personalities line up in his historical dramas of epic dimensions as embodiments of the national character. Historical film genre in the period of communism, often blending history and melodrama, reinforced a mythical image of history and played a significant role in the edifice of the ruling ideology as it was meant to arouse patriotic sentiments and national nostalgia.

The Romanian historical film tradition is playfully-reflexively evoked by Nae Caranfil in his The Rest is Silence (2007), which reinvents the conditions of shooting the first Romanian historical film, at the same time the first Romanian feature film, The Independence of Romania. Nae Caranfil's reflexive return to the beginnings of Romanian film history reveals the strong interconnectedness between cinema and historical representation and also provides a distantiating enframing of history. Both Nae Caranfil and Radu Jude avoid the quasi-obligatory micro-realist representation, which dominates New Romanian Cinema, and ingenuously reframe the genre of historical film. While the former chooses an overtly reflexive form within the confines of the feature film, the latter resorts to a more covert form of reflexivity by apparently letting loose the toolkit of historical film and creating the immersive frame of historical illusion but actually juxtaposing this toolkit with another one that systematically undoes the created historical illusion, resulting in a highly subversive form that puts in quotation marks the film's historical format.

The preoccupation of New Romanian Cinema with the past - the recent past most of the time - is rooted in the urge to understand the social and interpersonal mechanisms, deeply rooted in the communist past, of the present post-communist condition. Thus, those films that reach beyond the sphere of the strict present tend to remain within the span of social time that Jan Assmann (2008) relates to communicative memory, characterized by the proximity to everyday interaction and communication, embracing at most 80-100 years, that is the time span of three or four interacting generations. Within this time span, the 1989 events occupy an

2 E.g. The Dacians (Dacii, 1966), Michael the Brave - The Last Crusade (Mihai Viteazul - Unirea, 1971), War of Independence (Războiul Independenței, 1977), We Were in the First Line (Noi cei din linia întâi, 1985), Mircea (1989). 
eminent position, dealt with in several films. ${ }^{3}$ The connectedness to the present of communicative memory and the anniversary character of the past historical event institutionalized by cultural memory is "bridged" in Cristi Puiu's short film Das Spektrum Europas (2014), created within the documentary film anthology Bridges of Sarajevo, ${ }^{4}$ reaching the upper limit of the time span of communicative memory as defined by Assmann. Christian Ferencz-Flatz compares Cristi Puiu's aforementioned film and Radu Jude's Aferim! in terms of a related preoccupation, namely the nexus between the present and the past. What links the two concepts, according to Ferencz-Flatz, is the resorting to the procedure of citation, the literary reference as well as the form in which these films approach the issue of history; what distinguishes them is that while Puiu approaches history from the present and conceives of history as a domain that has become virtually inaccessible due to the prejudices of the present, Jude approaches the present from the direction of history and reveals the direct correspondence between the prejudices of the past and those of the present (Ferencz-Flatz 2015, 122-123).

Jude reaches far back in early $19^{\text {th }}$ century, that is no longer within the span of communicative memory, but a more remote past - in illo tempore - that forms part of cultural memory ${ }^{5}$ embracing historical, mythical, cultural time in Assmann's use of the term. Aferim! seeks to displace rather than to reinforce the mythical dimension of the Romanian historical past, and challenges Romanian national identity by evoking profoundly non-heroic genre images that do not fit into the canonical image of national history. The canonical image of the nation is superseded by a transnational landscape ${ }^{6}$ that involves Romanian peasants,

3 E.g. 12:08 East of Bucharest (A fost sau n-a fost, Corneliu Porumboiu, 2006), The Paper Will Be Blue (Hârtia va fi albastră, Radu Muntean, 2006) or Three Days till Christmas (Trei zile până la Crăciun, Radu Gabrea, 2011).

4 In the omnibus film project Bridges of Sarajevo (Les ponts de Sarajevo, 2014), occasioned by the World War I centenary, 13 film directors, among them also Jean-Luc Godard, explore the ways in which Sarajevo has inscribed itself into European history and reflect various artistic perceptions of today's image of the city. It was projected in the Special Screenings section at the 2014 Cannes Film Festival. Cristi Puiu's short film Das Spektrum Europas borrows its title from Hermann von Keyserling Baltic German philosopher's book published in 1928, which is read and commented on in bed by a retired couple (Valeria Seciu and Marian Râlea), spiced up by a great deal of ethnic stereotypes and prejudices.

5 Jan Assmann formulates the interrelatedness of memory and identity as follows: "Memory is knowledge with an identity-index, it is knowledge about oneself, that is, one's own diachronic identity, be it as an individual or as a member of a family, a generation, a community, a nation, or a cultural and religious tradition" $(2008,114)$. What has been a commonplace ever since John Locke, namely that identity and individual memory are indispensably interlocked, applies in the same measure to the nexus between (individual and collective) identity and cultural memory.

6 The transcultural perspective of the film is enlarged by the transnational - Romanian, Bulgarian, Czech and French - alliance of production. 
Turkish-influenced boyars and Gypsy slaves, and enriched by a multitude of ethnic groups whose stereotypical images turn up in the characters' conversations. The Orthodox priest, one of the various representatives of society whom the constable and his son meet on the road, enumerates, like a live Völkertafel, the stereotypes of various nationalities. His discourse is a hilarious collection of ethnic stereotypes; the prejudiced Gypsies occupy the last position in the line of clichés as ones whose subjugation is set in stone: "Each nation has its purpose. The Jews, to cheat, the Turks, to do harm, us Romanians to love, honour and suffer and like good Christians. And each has their habits. Hebrews reads a lot, Greeks talks a lot, Turks has many wives, Arabs has many teeth, Germans smoke a lot, Hungarians eat a lot, Russians drink a lot, English think a lot, French like fashion a lot. Armenians are lazy, Circasians wear many a lace, Italians lie a lot, Serbians cheat a lot and Gypsies get many a beating. Gypsies must be slaves. When Ham spread horse shit on Noah, Noah cursed them to be slaves and as dark as shit.' 'That's right.' 'They must be kept on a tight leash. 'Tis a holy commandment."' Besides ethnic stereotypes, the film presents a view of social order based on xenophobia, homophobia and sexism, which comes to light on the road, in the dialogues between various characters.

Jude's film brings to the fore an ethnically mixed society in which different ethnic groups occupy distinct positions in the rigidly hierarchical social organization. The main narrative thread unfolds around the prejudiced Gypsies; the Orthodox priest asks the question whether the Gypsies are men or descendants of the devil itself; however, Carfin, the Gypsy slave to be punished possesses the widest view of the world as he is the one who has travelled the most. The boyar's Turkish word, Aferim! (i.e. Bravo!) with which he appreciates Costandin for finding the runaway Gypsy slave, ironically overwrites the burdened, hierarchical Romanian-Gypsy relation as the third in the actual possession of power. Social interactions are staged in a series of episodes in which every single dialogical situation, whether between the constable and his son, the constable and the boyar, the boyar and his wife, is hierarchical, and almost every member of the nation (with the exception of those in the lowest position in the hierarchy, the Gypsy slave and the child) reproduces the experienced social relations of inequality at the first available opportunity.

Aferim! is the first Romanian film that brings up the issue of Gypsy slavery. However, albeit dealing with this social-historical taboo, it is not its main purpose to recontextualize and speak about slavery as such. ${ }^{7}$ Instead, it aims to face the

$7 \quad$ For a historical approach to Gypsy slavery under the Romanian ancien régime, see Viorel Achim (2004, 34-42). 
present spectators with their own racism, it holds up a mirror reflecting present social attitudes towards the Other. In this way, the temporal distance between the viewers' present and the represented historical time is cut short by the created interferences between the premodern past and the - supposedly - postpostmodern present; a profound preoccupation with today's (mal)functioning of society, especially with the historical reasons for it, filters through the historical template, the representation of the past acquiring thus allegorical overtones.

In his seminal essay on Historical Allegory Xavier points at the "essential connection between allegory and the vicissitudes of human experience in time" (2004, 333). Allegorical discursive practices, Xavier claims, emerge in periods of social crisis; modern culture, so tightly conjoined with allegory ever since Walter Benjamin's reconceptualization of the notion, presents "a new awareness of instability" that "only enhances an old perception of the problematic character of signifying processes, a perception that is nowadays taking us from the lost paradise of transparent languages" (Xavier 2004, 333). Xavier's essay dwells on the role allegory in its modern form plays in diverse cultural processes, from high art forms to popular culture, present in all sorts of traditional popular genres. Aferim! is a unique experiment in that it explores the allegorical potential of various genres and discursive practices. By resourcefully activating the cinematic codes of popular genres such as the western or the historical film, Jude's artistic achievement offers a subtle reading and a disconcerting view of the early $19^{\text {th }}$-century Romanian realities as the allegory of present social relations and mentalities infused with stereotypical thinking and prejudices.

If we regard the narrower definition of the historical film, provided by Natalie Zemon Davis, according to whom historical film is "a genre composed of dramatic feature films in which the primary plot is based on actual historical events, or in which an imagined plot utilizes historical events, making them central to the story" (Davis 2000, 5), then the mere utilization of a historical setting - Wallachia, 1835 -, as in the case of Aferim! [Fig. 1.], is not enough for the generic inclusion. Obviously, Aferim! does not struggle for such an inclusion. It is not centred on any particular historical event; it rather presents a sweeping panorama of $19^{\text {th }}$ century Wallachian society [Fig. 2.], caught in emblematic instances frequently occurring in Romanian literature and film (e.g. the fair, the inn). The plot that lacks a "proper" historical event is loosely strung on a narrative thread, deliberately slipping from under the generic authority of the historical film.

The archaization of images, the impression of archival footage, the employment of a static camera and of tableau compositions with many figures imitate the 
style of early film tradition. The representation of peasant figures also connects back to the literary and cinematic traditions, e.g. to social tableaux in Aristide Demetriade's The Independence of Romania or Stere Gulea's The Moromete Family (Moromeții, 1987) as possible media-archaeological traces. Here, however, the social fresco is not idealized, nor merely realistic but caricatured and grotesque (see the recurrent tableau compositions with many peasant figures who turn their back to the camera). Thus, the tableau is employed not as the lieu of pathos but that of irony. The grotesque social tableaux are counterpointed with painterly landscape tableaux, grabbing "reality" in the opposite extremes of social caricature and the romantic wilderness of nature. [Figs. 3-4.] The tableau may be perceived in the film as a marker of the historical film format, evoking the epic grandeur that classical historical films strive for. In his essay Ismail Xavier $(2004,354)$ mentions "suggestive examples of historical narratives where magnified visual spectacle serves as a kind of animated national monument or tableau vivant. The mobilization of material resources, technical skills, and the proverbial 'cast of thousands' could be exhibited as a sign of a nation's (or a social regime's) strength and legitimacy." The epic grandeur and "figural totalization" (Xavier 2004, 358) that the historical tableau carries in itself is here undermined by the subversive, profoundly nonheroical representation and the lack of "appropriate" content, i.e. battle scenes or other historical events displaying a totalizing view of the "national character."

The film simultaneously constructs and deconstructs the illusion of historical reality. It unfolds in the in-betweenness of the seemingly "natural," unmediated, and the artificial, mediated, that can be grasped in terms of the "twin logics of immediacy and hypermediacy" of cinematic experience (Bolter and Grusin 1999, 5). On the one hand, the film creates the impression of historical reality as an experience of immediacy through a series of devices: period mise en scène informed by a vast amount of visual (illustrative, photographic, painterly and cinematic), historical and literary material, created through both the profilmic (setting, costumes, the characters' way of speaking and behaving) and the style of cinematic mediation, through vast static tableaux and photographic images with archival footage effect, further archaized by the employment of fade-in and fade-out. On the other hand, the effet de réel is overwritten by the hypermediacy of cinematic experience. Aferim! is in fact a hypermediated patchwork of diverse medial representations that can be best grasped in terms of intermediality. The film displays a simple linear plot imbued with a dense dialogue in archaic Romanian, drawn from a multitude of literary and historical sources (not fully comprehensible perhaps for the native Romanian viewers either; the English 
subtitles only epitomize all that is being said in the dialogues). The characters converse in parables with moral lessons that are taken from $19^{\text {th }}$-century Romanian texts; ${ }^{8}$ the literary material is ingenuously arranged in a way as to make possible a narrative thread, but the artificiality of the spoken words, the tension between the formal, written text poured into the informal speech situations is sustained throughout the film. The painterly quality of the images is provided by vast tableaux, associated with the employment of fixed frontal camera position, long takes, extreme long takes and awkward compositions evoking the theatricality of the early film. The effect of authenticity is thus counterpointed by a high degree of assumed artificiality and constructedness.

Radu Jude's Aferim! has been labelled by reviewers as a "Romanian Gypsy western." The generic affiliation to the western is announced on a blue and red coloured movie poster; the harsh coloured poster is in sharp contrast with the film's soft black-and-white texture. [Figs. 5-6.] The generic code of the western provides the narrative pattern ("man-hunt:" search for the runaway slave; conflicts among nations situated at different stages of development; punishment), the temporal positioning (early $19^{\text {th }}$-century historical milieu), the sense of the place (backward rural scenes; wild violence as part of the daily life; the Romanian countryside as a "frontier zone") and also the inclination for stereotypes as well as the retrograde, racist, colonial attitude (the finding of the Gypsy slave and punishment from a morally superior position taken for granted). The western hero, lonely and of a masculine integrity, is enacted here by the two protagonists, the constable and his son. The constable is old and coughs heavily all through the film; his cough is apparently disruptive rather than motivated, but it actually serves as a displacement of the western generic code and of the immersive frame of historical representation. The film places in the position of the hero a vulnerable and in fact passive man, an anti-hero who obsequiously follows the orders of the boyar without critically reexamining them and who, in his continuously asserted moral judgements attesting his intolerant, colonial views, proves to be an unreliable and fallible character, not providing the possibility of identification for the spectator. Even the quasi-heroical act of finding the Gypsy slave is undermined: by the boyar himself within the diegesis, who verbally humiliates the constable in front of his son, and by the whole heterogeneous material that makes up the film narrative as a whole.

8 The compilation of literary fragments from $19^{\text {th }}$-century Romanian writers - Iordache Golescu, Anton Pann, Ion Creangă, Nicolae Filimon, Ion Budai-Deleanu and others - praise the work of the script writers Radu Jude and Florin Lăzărescu. 
The generic clichés of the western applied to the archaic Romanian society also invoke the "eastern"9 as a generic reference; Jude's film explores to the most all the dissonances and tensions created in this cultural gap. The linear film narrative, the two protagonists' being on the road from the beginning to the end of the story, is reminiscent of the narrative construct of road movies; in this respect, again, the tension between the modern-time road movies and the premodern journey on horseback can be perceived. The evoked and displaced generic references result in a generic collage relying on the juxtaposition of diverse visual codes and clichés. The images activate this layeredness already at the very beginning: during the opening credits there appears the image of a thistle swaying in the wind [Fig. 7]; it may be the "eastern" correspondent of the vegetal stereotypes of the western, at the same time, it bounds the image to the region as the typical local weed and also a possible symbol of the social wilderness and uncultivatedness that the film will represent. Together with the accompanying music, it creates the specific atmosphere of a "Balkan western" as Aferim! has also been called. The simultaneity of distinct codes anticipates the multiple layeredness of the film; these generic and cultural layers are superimposed and result in a heterogeneous collage of genres and representational modes.

Viewing Aferim! is a complex cinematic experience that allows for the activation of a wide range of cinematic references, overt and covert allusions and image types that associate particular genres if not particular films. The perception of the visual layeredness of the film can be conceived along the concept of allegory, which in narrative film "is not simply produced by a storytelling process involving agents and actions, but also results from visual compositions that, in many cases, establish a clear dialogue with particular iconographical traditions, ancient and modern. Depending on the particular editing strategy adopted, a filmmaker can privilege the horizontal, narratological, succession of shots to create specific space-time structures of action, or can privilege the vertical relationships created by the interaction of image and sound, or by the intertextual connections between the film's pictorial composition and cultural codes deriving from painting and photography" (Xavier 2004, 337). Jude's film preeminently initiates a dialogue with particular iconographic traditions, within and beyond Romanian (cinematic) culture. Besides the aforementioned elements of the western manifesting at the "horizontal level," the film is infused with elements that exert their effect at the

9 An interesting connection, worth thinking over, is provided by the film Mirage (Délibáb, Szabolcs Hajdu, 2014), a Hungarian "eastern" about slavery in contemporary days set in the Hungarian Puszta [wasteland], having as its protagonist a runaway black football player enslaved by a tyrannical Romanian slave owner and his Gypsy fellows. 
"vertical level," thus requiring a "multi-focal cultural gesture” that Xavier regards as being characteristic of allegorical reading: "reading films allegorically is always a multi-focal cultural gesture, requiring the capacity to explore what is suggested both by the horizontal succession of shots and by the vertical effects of visual compositions or cultural codes embedded on its soundtrack" (2004, 337). Aferim! goes against a smooth integration of vertical effects and cultural codes, instead, it plays off one cultural code against the other, at least, preserves the underlying tensions, resulting in a masterful patchwork of cliché images and cultural codes.

The collage effect also manifests in the sound-image relation. In the opening shot, which is an extreme long take recorded with a fixed frontal camera, there turns up an empty landscape which is first filled with the voices of the conversing protagonists approaching on horseback, but they cannot yet be seen. While the spectator follows the horseriders turning up and entering the image on one side, their voices remain in a constant, unaltered proximity until the characters leave the image on the other side, without the camera following them. [Figs. 8-9.] Thus, the landscape tableau emerges with the power of creating an immersive spatial background for the anticipated action, but due to the "two-dimensional" use of the soundtrack, to the "archaization" of the technique, this immersive structure is overwritten by a bizarre dissonance which will only be amplified by the unique constructedness of the film. The dissonant sound-image structure - tableaux recorded in extreme long takes with distant, dot-like characters and their voice added in "close-up" - will be repeatedly employed, reinforcing the artificiality and laying bare the mediatedness of "historical reality."

Just as incorporating literary quotes, Aferim! also relies on cultural codes (photographic and painterly representations of the $19^{\text {th }}$-century Romanian society) and intertextual connections (manifold cinematic references). The space construction of the film and the recurrence of social tableaux carry many of these covert references. The road movie type narrative pattern allows the inclusion of a great diversity of landscapes that serve as the background of the protagonists' quest but also as markers of architextual connections. The large, open-air, empty spaces grabbed in landscape tableaux may evoke the genre of the western including the Romanian spaghetti westerns and perhaps also the Mărgelatu series..$^{10}$ The "mioritic"11 foothills call forth the space representation in Romanian historical

10 Popular adventure films set in the historical past, directed, in turn, by Doru Năstase, Gheorghe Vitanidis and Mircea Moldovan in the eighties, with the famous Romanian actor, Florin Piersic in the main role.

11 "Blaga, a renowned inter-war poet and philosopher, advanced the concept of the Spațiul Mioritic (the Mioritic Space), which provided a definition of the Romanian national identity 
films, albeit with perceivable differences that subvert the idyllic space that is one with the nation (e.g. in Sergiu Nicolaescu's The Dacians); the journey through the foggy forest may evoke in the spectator the ending of Stere Gulea's already mentioned The Moromete Family. Aferim! subtly brings in motion these implied spatial references with a discrete media-archaeological purport. ${ }^{12}$

The collage effect disrupts the veil of the illusion of historical reality, which is only reinforced by goofs. Christian Ferencz-Flatz espies and interprets goofs, intentionally left within the final version of the film, as forming part of the film's moments of oscillation between diegesis (realist representation) and metadiegesis (breaking the illusion of realist representation). He draws attention to moments in the film when actors make mistakes while shooting, for instance, the actor playing the Orthodox priest on the road (Alexandru Bindea): in the course of the perhaps funniest scene of the film the horse of his cart moves in the wrong direction and the priest suddenly looks into the camera with remorse in his eyes [Fig. 10]; or, at a certain point towards the end of the film the actress playing the boyar's wife (Luminița Gheorghiu) addresses the constable, Costandin, by mistakenly using the Gypsy slave's name: "Carfine," and she is also confused in front of the camera for a brief, hardly noticeable moment (cf. Ferencz-Flatz 2015, 129-130). Besides, the film that Christian Ferencz-Flatz qualifies as a "well-spoilt film" in the title of the above reference also resorts to temps morts, metaleptic moments and occasionally deliberate clumsiness of shooting.

Through its ingenuous intermedial solutions, Aferim! is deemed a collage of life and artifice, rendering the historical "reality" in a series of audio-visual, generic and cultural stereotypes, relieving the historical image from under the convention of mythical or realistic representation. The collage as the film's major structuring principle and figurative potential disrupts the veil of the illusion of historical reality, pointing at the artificiality of history as construct. In contrast with the homogeneous construction of historical representation in traditional historical film, the intermedial constructedness of Aferim! brings to the fore a

through a combination of environment and culture. The environment helped to shape the Romanian lifestyle and the Romanian lifestyle helped to shape the environment." (Lowatt 1999.)

12 The question arises how a film so deeply embedded in the Romanian social, cultural and historical context "is readable" for spectators unfamiliar with these cultural reminiscences. The international recognition and popularity of the film attests that Aferim! does exert effect among non-Romanian viewers as well, due to its ingenious film language solutions, its humour and the human patterns perpetuated across times and spaces: "And yet, as with so many Romanian films, Radu Jude's approach is one of deadpan humour, born from a world-weary culture grappling with a bumpy history that seems to have only one constant: people were made to suffer" (Hoffman 2016). 
fragmented image of the historical past, shattered into pieces by diverse media representations. Aferim! as a media collage engaged in a dialogue with history extends the possibilities of the structural mode of intermediality that, according to Ágnes Pethő, "may take the form of diegetic reflexivity, or it may result in the world appearing as a media collage, it can be perceived as a marker for metaleptic leaps, intermediality may perform metaleptic constrasts between the 'natural,' the seemingly unmediated and the artificial within the image, as well as 'folds' of the immediate and the mediated (applying Deleuze's well-known concept to intermedial cinema)" (Pethő 2011, 5-6).

Through its sophisticated reflexivity and unconcealed criticism, Radu Jude's bittersweet, ironical intermedial collage defetishizes the traditional historical iconography and debunks the mythical national imaginary, unveiling the traumatic history of an ethnic and racial mix and opening up the historical perspective as a grain of thought for the present.

\section{References}

Achim, Viorel. 2004. The Roma in Romanian History. Budapest: Central European University Press.

Assmann, Jan. 2008. Communicative and Cultural Memory. In Cultural Memory Studies. An International and Interdisciplinary Handbook, eds. Astrid Erll and Ansgar Nünning, 109-118. Berlin and New York: Walter de Gruyter.

Bolter, Jay David and Richard Grusin. 1999. Remediation. Understanding New Media. Cambridge, Massachusetts and London: The MIT Press.

Davis, Natalie Zemon. 2000. Slaves on Screen: Film and Historical Vision. Cambridge, MA: Harvard University Press.

Erll, Astrid. 2008. Literature, Film, and the Mediality of Cultural Memory. In Cultural Memory Studies. An International and Interdisciplinary Handbook, eds. Astrid Erll and Ansgar Nünning, 389-398. Berlin and New York: Walter de Gruyter.

Ferencz-Flatz, Christian. 2015. Apendice: Aferim! - un film bine stricat. [Appendix: Aferim! - A Well Spoilt Film.] In Incursiuni fenomenologice în noul film românesc. [Phenomenological Incursions into New Romanian Cinema], 122-132. Cluj-Napoca: Editura Tact.

Hoffman, Jordan. 2016. Aferim! Review: a Brutal Manhunt Loaded with Laughs. The Guardian January 20. https://www.theguardian.com/film/2016/jan/20/ aferim-review-a-brutal-manhunt-loaded-with-laughs. Last accessed 20. 08. 2016. 
Lazăr, Veronica and Andrei Gorzo. 2014. Aferim! - ceva nou în cinemaul românesc [Aferim! - Something New in Romanian Cinema]. In Politicile filmului. Contribuții la interpretarea cinemaului românesc contemporan [The Politics of Film. Contributions to the Interpretation of Contemporary Romanian Cinema], eds. Andrei Gorzo and Andrei State, 301-312. Cluj Napoca: Tact.

Lowatt, Catherine. 1999. The Mioritic Space. Romanian National Identity in the Work of Lucian Blaga. Central Europe Review vol. 1, no. 18 http://www.cereview.org/99/18/lovatt18.html. Last accessed 15. 08. 2016.

Pethő, Ágnes. 2011. Cinema and Intermediality. The Passion for the In-Between. Newcastle upon Tyne: Cambridge Scholars Publishing.

Skrodzka, Aga. 2012. Magic Realist Cinema in East Central Europe. Edinburgh: Edinburgh University Press.

Vidal, Belén. 2012. Heritage Film: Nation, Genre and Representation. New York and Chichester: Columbia University Press.

Xavier, Ismail. 2004. Historical Allegory. In A Companion to Film Theory, eds. Toby Miller and Robert Stam, 333-362. Oxford: Blackwell Publishing.

\section{List of Figures}

Figure 1. Historical setting in Aferim! (Radu Jude, 2015).

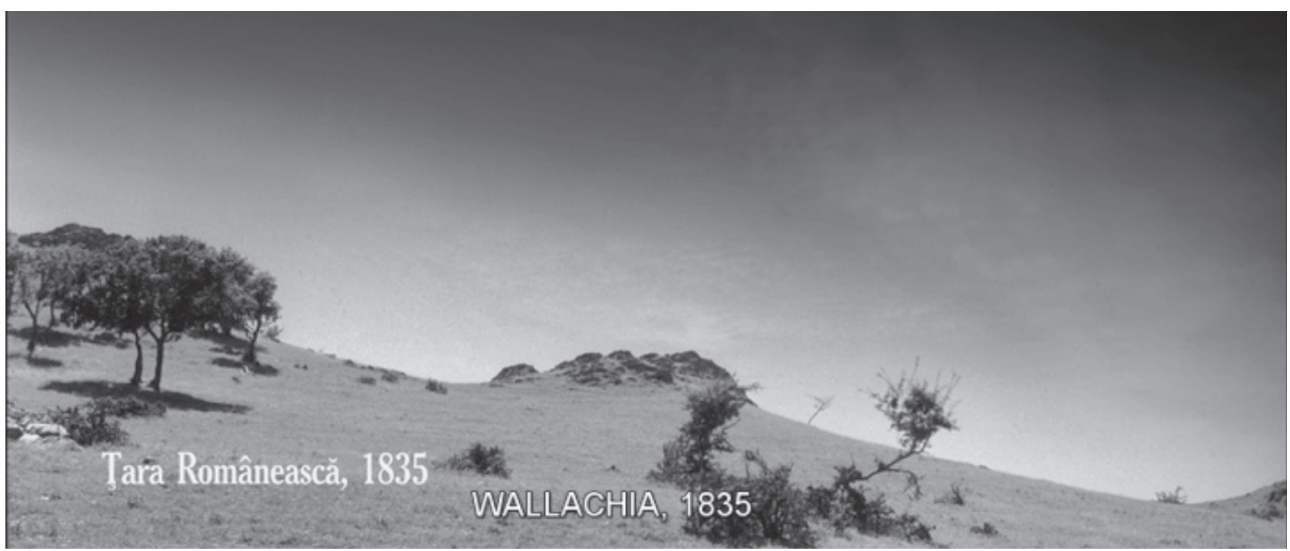


Figure 2. The fair. A sweeping panorama of the $19^{\text {th }}$-century Wallachian society in Aferim!.

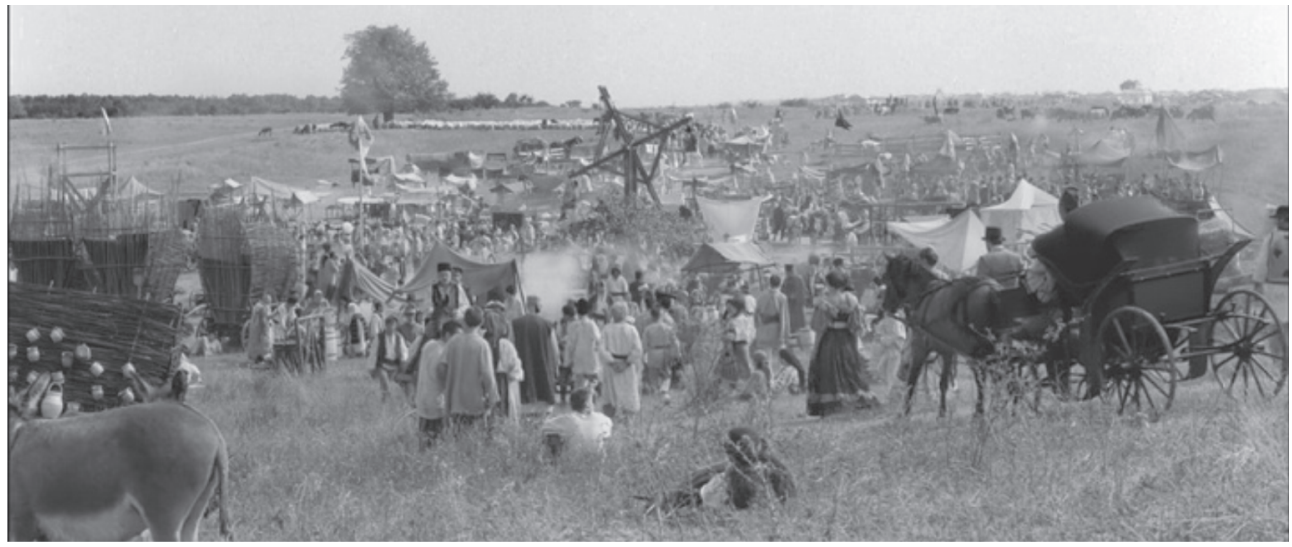

Figures 3-4. The contrast of grotesque social tableaux and painterly landscape tableaux.
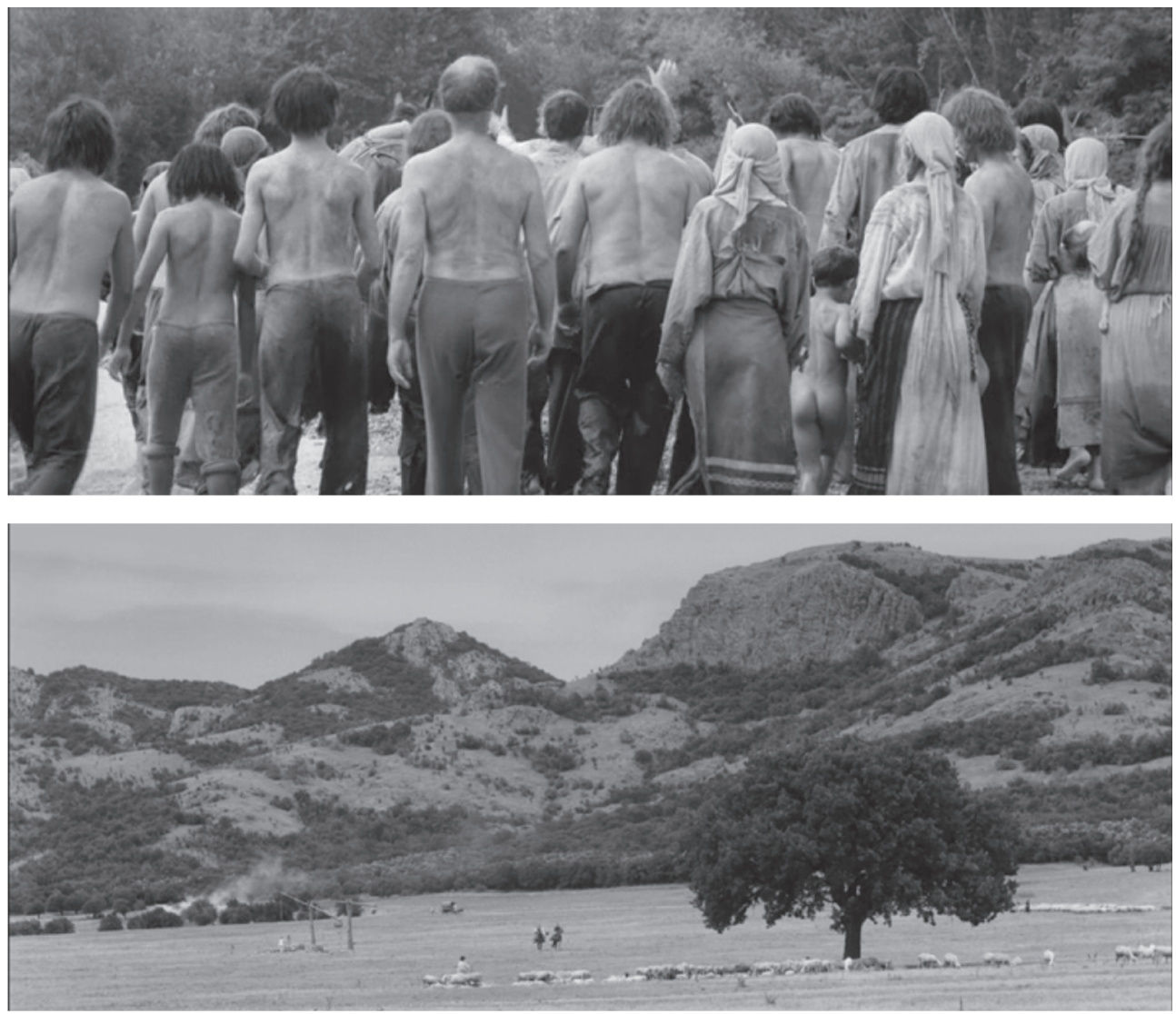
Figures 5-7. Aferim! as a "Romanian Gypsy western."
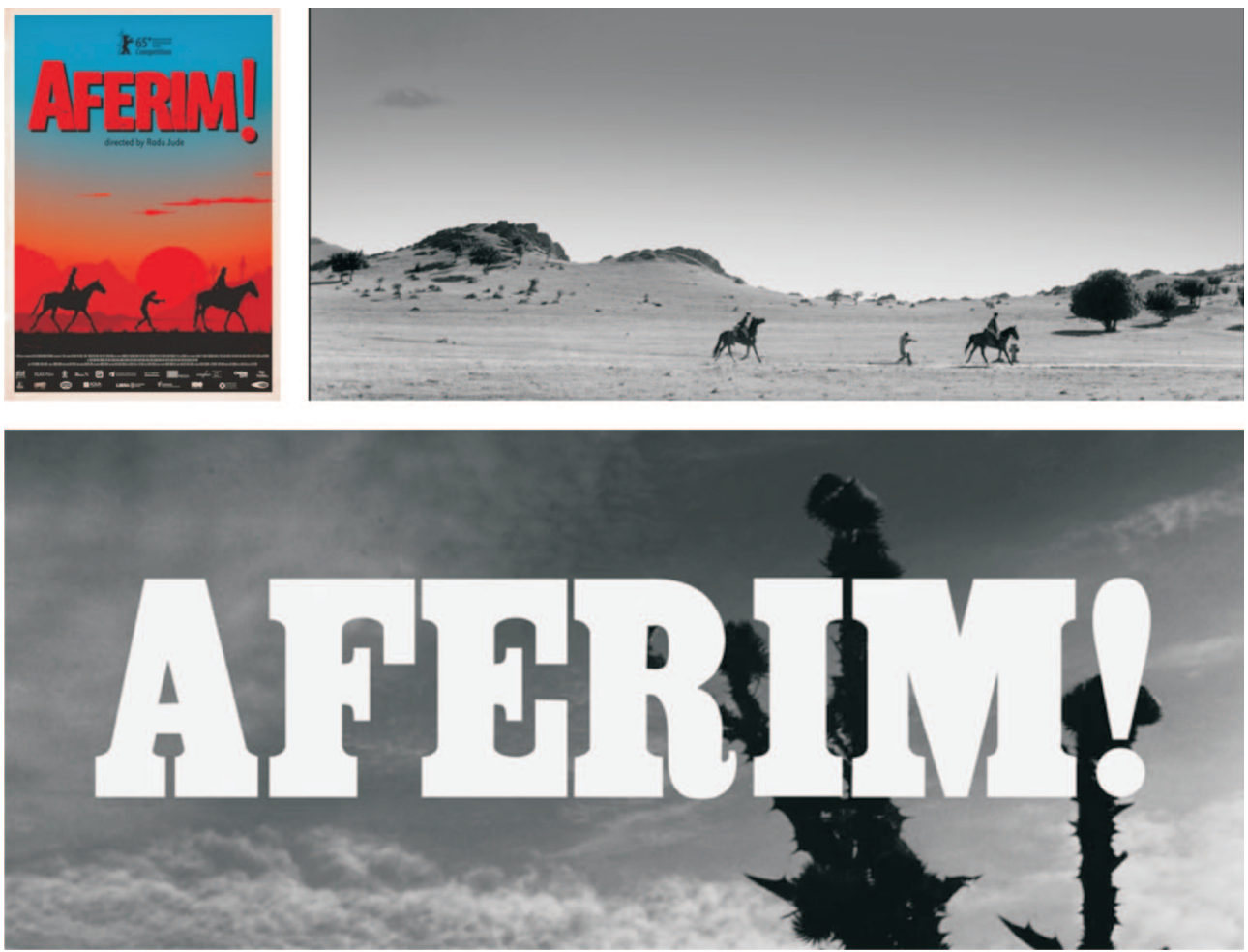

Figures 8-9. Sound-image collage in Aferim!.

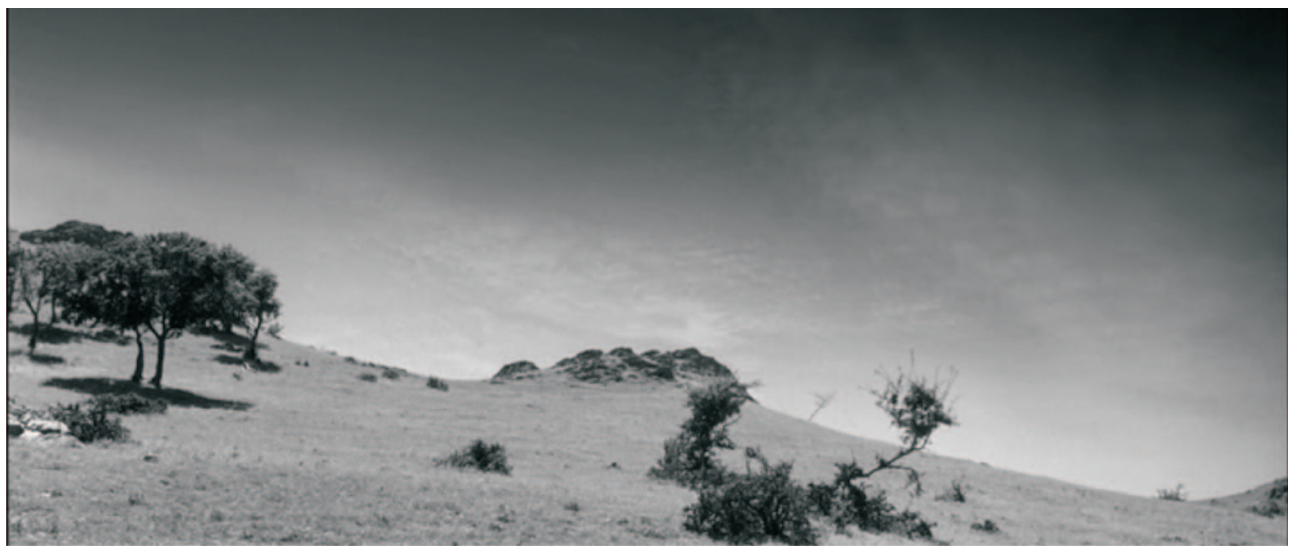




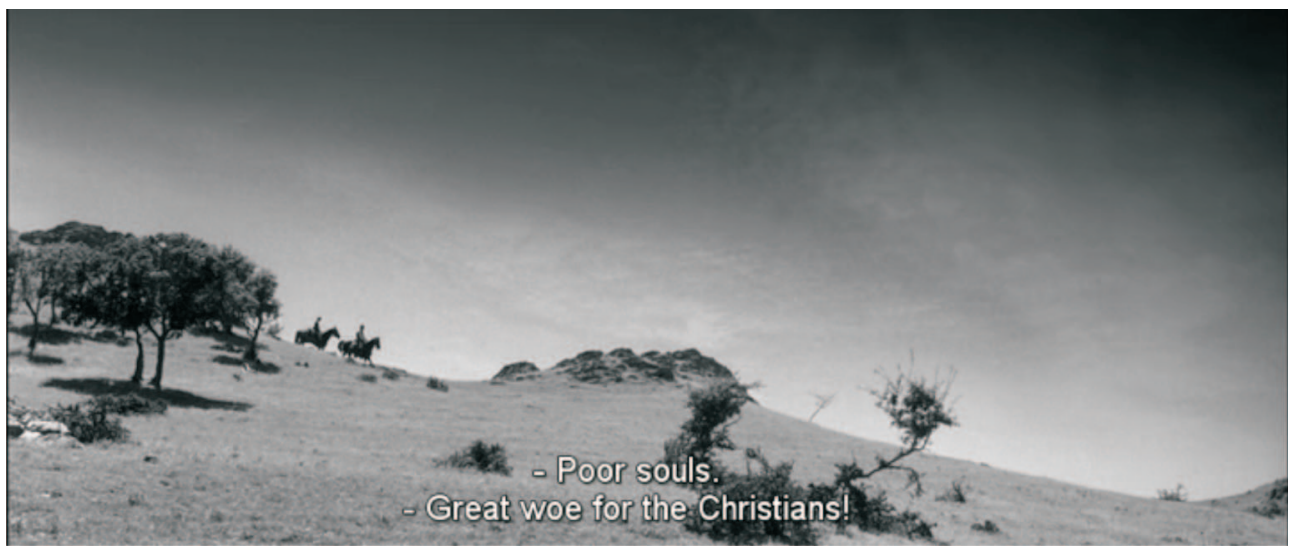

Figure 10. A "derail” in the course of shooting: a goof deliberately left in the final version of Aferim!.

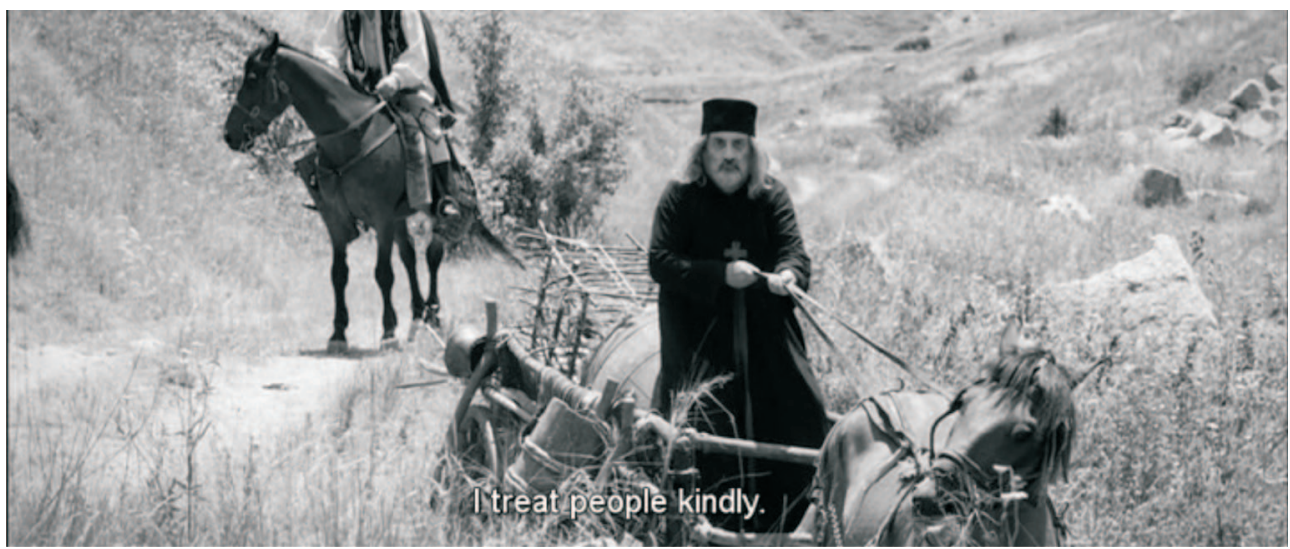

